\title{
Prospective study of power generation from natural resources using hybrid system for remote area
}

\author{
M.F.Yaakub ${ }^{1}$, F.H. Mohd Noh², M.F.I Mohd Zali ${ }^{3}$, M.H. Harun ${ }^{4}$ \\ ${ }^{1,3,4}$ Fakulti Teknologi Kejuruteraan Elektrik dan Elektronik, Universiti Teknikal Malaysia Melaka, Malaysia \\ ${ }^{1,4}$ Cantre of Robotic and Industrial Automation, Universiti Teknikal Malaysia Melaka, Malaysia \\ ${ }^{2}$ Fakulti Teknologi Kejuruteraan, Universiti Tun Hussein Onn Malaysia, Malaysia
}

\begin{tabular}{l} 
Article Info \\
\hline Article history: \\
Received Sep 6, 2019 \\
Revised Nov 9, 2019 \\
Accepted Nov 23, 2019 \\
\hline Keywords: \\
Energy conversion \\
Hybrid \\
Pico-hydro \\
Rainfall \\
Solar energy
\end{tabular}

\begin{abstract}
Living in the 21 st century, electricity has become a need in every society level. However, numbers of the remote area, especially in third world countries still facing difficulty to reach a grid-connected electricity due to various reasons. As such, this paper presents a prospective study of generating an electrical energy that is converted by utilizing natural resources from the sky. It is realized by implementing a hybrid solar-rainwater harvesting system. Combination of $12 \mathrm{Vdc} 3 \mathrm{Watt}$ solar cells and $3.7 \mathrm{Vdc}$ $129 \mathrm{~mW}$ pico-hydro implemented in the work has given a great yield reaching average 921 milliwatts of energy produced by the natural resources.
\end{abstract}

Copyright () 2020 Institute of Advanced Engineering and Science. All rights reserved.

\section{Corresponding Author:}

Muhamad Faizal Yaakub,

Fakulti Teknologi Kejuruteraan Elektrik dan Elektronik,

Universiti Teknikal Malaysia Melaka,

Hang Tuah Jaya, 76100 Durian Tunggal, Melaka, Malaysia.

Email:muhamadfaizal@utem.edu.my

\section{INTRODUCTION}

In 2006, there were significant numbers of areas in Malaysia that had no access to 24-hours electricity. Extension of grid electricity networks becomes wasteful because of the geographical conditions of these areas, even with demand from the citizen [1]. Hence, an independent energy generator could be the best alternative to mitigate this issue.

Recent studies reveal there are various works have been done to generate an electricity from the natural resources and agricultural waste [2-18]. However, a major problem of single source power generation is its dependence on weather condition which sometimes unpredictable, especially in the tropical climate region. Therefore, a hybrid approach is fast becoming a key instrument in energy conversion. For instance, an integrated electricity system that harvests energy from combined wind-solar has been introduced by N.Sivaramakhrisna et.al. in 2013 which aimed to gain an uninterruptable power supply in various weather condition [19]. Research on hybrid energy conversion system continuously emerged when recently Pico-hydel hybrid power generation system with open well energy storage is being introduced by a group of researcher from India. Research led by Anilkumar has proposed an approach for off-grid microhybrid system model which comprised of wind and solar energy as primary sources together with pump storage unit [20]. The simulation done in [20] discovers it could produce almost $500 \mathrm{~W}$ of power at a peak. Unlike Sivaramakhrisna and Anilkumar, Vinesh (2015) used only two resources for his hybrid system i.e. wind and solar. Interestingly, the work was carried out in tropical climate region where wind speed is not so significant for energy harvesting. However, with custom made wind turbine type, he and his co-workers are able to produce amount of energy, approximately 0.7 watt where Kota Kinabalu was chosen as a testing site 
for their system $[21,22]$. On the other hand, it is far too little attention has been paid on combining sun rays and rainwater to breed electrical energy to consumer.

Although Malaysia does not suitable for wind energy harvesting, it is geographically found in an equatorial region where a huge amount of rain and sun rays are received each year. This claim is proven when Syafrina (2014) and her team tabulated the historical rainfall trend in Malaysia between 1975 to 2010. Syafrina characterised the intensity in four different seasons i.e. the northeast monsoon (November-February) known as NEM, the southwest monsoon (May-August) known as SWM, and two inter-monsoon seasons (March-April) MA and (September-October) SO. The analysis indicates an increasing trends of rain frequency in Malaysia within 1975 to 2010 with notable increasing trends in short temporal rainfall was observed during inter-monsoon season [23]. In short, Peninsular Malaysia and Malaysian Borneo side receive around $2500 \mathrm{~mm}$ and $5080 \mathrm{~mm}$ of rainfall, respectively in average each year [7].

As was pointed out earlier, Malaysia received huge amount of sun rays throughout the year. This statement is supported by Mekhilef et.al through their review in 2012. In average, Malaysia exposes to 400-600 MJ/m2 solar radiation per month. With an average sunshine duration of 4 to 8 hours per day and $4000-5000 \mathrm{Wh} / \mathrm{m} 2$ of solar radiation daily, it provides huge solar energy potential to the nation approaching to $2000 \mathrm{kWh} / \mathrm{m} 2$ yearly. Table 1 disclosed the average of solar radiation value in Malaysia throughout a year. Collectively, natural resources contain vast potential as a new energy source to cope with the high demand, especially in the remote area. With a combination of rainfall water and sun rays, this project aims to look into a prospective angle to generate an energy by deploying a rain-solar hybrid system that converting natural resources i.e. rainwater and sunrays into an electric energy [24].

\begin{tabular}{cc} 
Table 1. Solar Radiation in Malaysia per Year [25] \\
\hline Irradiance & Yearly average value \\
\hline Kuching & 1470 \\
Bandar Baru Bangi & 1487 \\
Kuala Lumpur & 1571 \\
Petaling Jaya & 1571 \\
Seremban & 1572 \\
Kuantan & 1601 \\
Johor Bahru & 1625 \\
Senai & 1629 \\
Kota Bharu & 1705 \\
Kuala Terengganu & 1714 \\
Ipoh & 1739 \\
Taiping & 1768 \\
Gorge Town & 1785 \\
Bayan Lepas & 1809 \\
Kota Kinabalu & 1900 \\
\hline
\end{tabular}

\section{METHODOLOGY}

\subsection{Hardware}

A prototype of an independent hybrid solar-rain energy generator has been developed in order to perform the experimental work. The prototype is built by combining a Pico-hydro together with a solar cell system to alternately produce an electrical energy regardless of weather conditions. As such, the maximum and uninterruptable energy production can be achieved. The gravitational force of water flow in the Picohydro system and solar radiation exposure from the sun is converted to useful energy form using two $12 \mathrm{Vdc}$ 3 Watt solar cells and a NACuM DB-370F 3.7Vdc 129mWatt micro-generator. Both energy conversion devices are installed in the power generator prototype as shown in Figure 1. The dimension of the prototype is illustrated in Figure 2. Maximum head of the energy harvester prototype is approximately two meters with 10 liters water tank mounted on top. The water tank is used to gather the rain water before it is released through the pico-hydro system's pipeline. In addition, two solar cells are connected in parallel with ' $\mathrm{V}$ ' shape configuration attached to the tank to collect the solar radiation. At the bottom, lie the micro-generator and the controller for the hybrid system. 


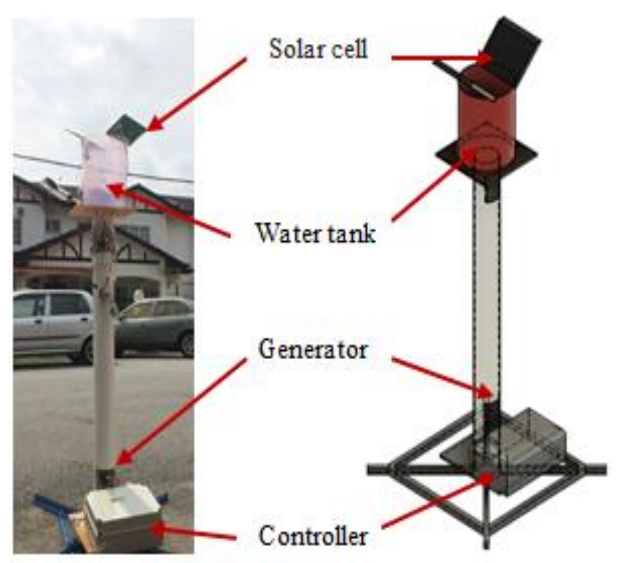

Figure 1. A prototype of hybrid solar-rain energy harvester

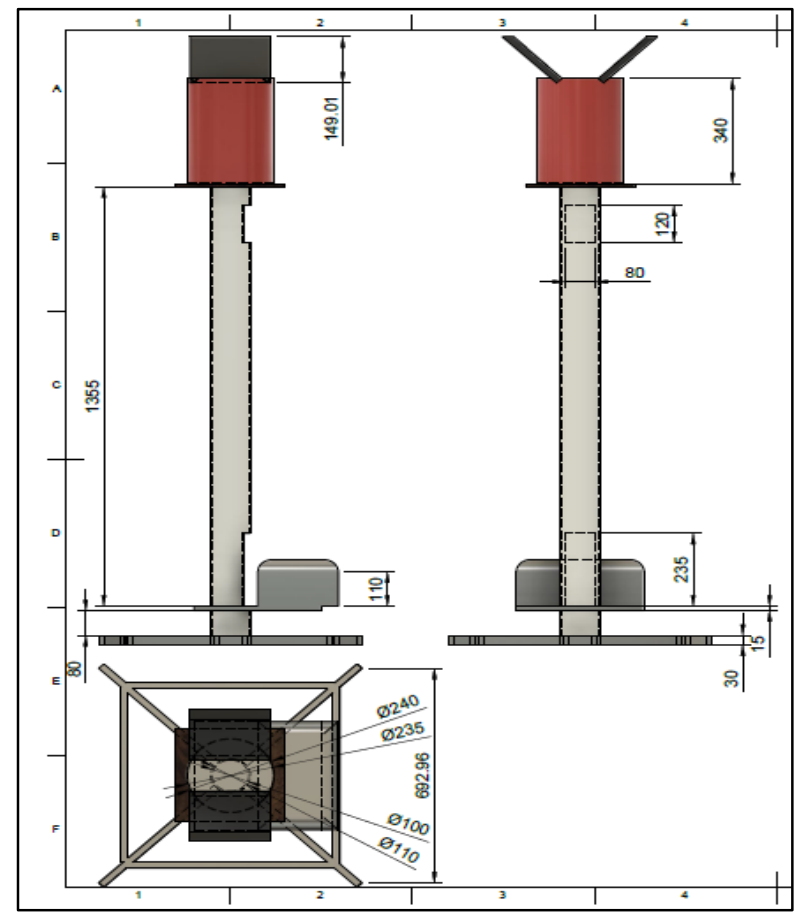

Figure 2. Technical drawing of hybrid solar-rain energy harvester prototype

\subsection{The Experiment}

The feasibility study of the prospective energy harvesting was done in three modes i.e. solar mode, pico-hydro mode, and hybrid mode. Rationally, this approach allows the authors to distinguish the individual capability of each module, as well as the hybrid system's proficiency. Pico-hydro mode experiment work was established by disabling the solar cell module. Ten liters of water was used in the experiment which produced ten different head values range, from 1.44 meters to 1.67 meters. This step was prepared according to the procedure used in [7, 22]. Data of voltage and current form the module were collected gradually using Graphtec Petitlogger GL100, GS-4VT Voltage sensor and GS-AC200A Current Sensor modules at different head levels. Forecasted energy yield by the Pico-hydro system is estimated by the (1) [24].

$$
P=Q \cdot H \cdot \rho \cdot g
$$

Where,

$P=$ Potential Power (watts)

$Q=$ Volumatric flowrate (litre/sec)

$H=\operatorname{gross}$ head $(m)$

$\rho=$ water density $\left(\mathrm{kg} / \mathrm{m}^{3}\right)$

$g=$ gravitational constant $\left(9.81 \mathrm{~m} / \mathrm{s}^{2}\right)$

On the other hand, solar mode experimental work was carried out by enabling only the solar cell module. The energy harvester prototype was exposed to sun rays from 8:00 am to 5:00 pm. Data form the module was collected using aforementioned apparatus at every 1-hour interval. Estimated energy yield from the solar radiation is forecasted by (2);

$$
E=A \cdot r \cdot H \cdot \mathrm{F}
$$

Where,

$E=$ Potential Energy $(k W h)$

$A=$ solar panel area $\left(\mathrm{m}^{2}\right)$

$r=$ solar panel yield or efficiency (\%)

$H=$ Annual average solar radiation on panel

$\mathrm{F}=$ Performnce ratio, coefficient for losses 
Ayer Keroh, Melaka was chosen as a testing site for the hybrid system. In an attempt to reveal the actual potential of energy from the rainwater and solar ray, the prototype harvester was placed under open sky for five days where the weather condition is shown in Figure 3. At this stage, both modules are switched on to form the hybrid configuration.

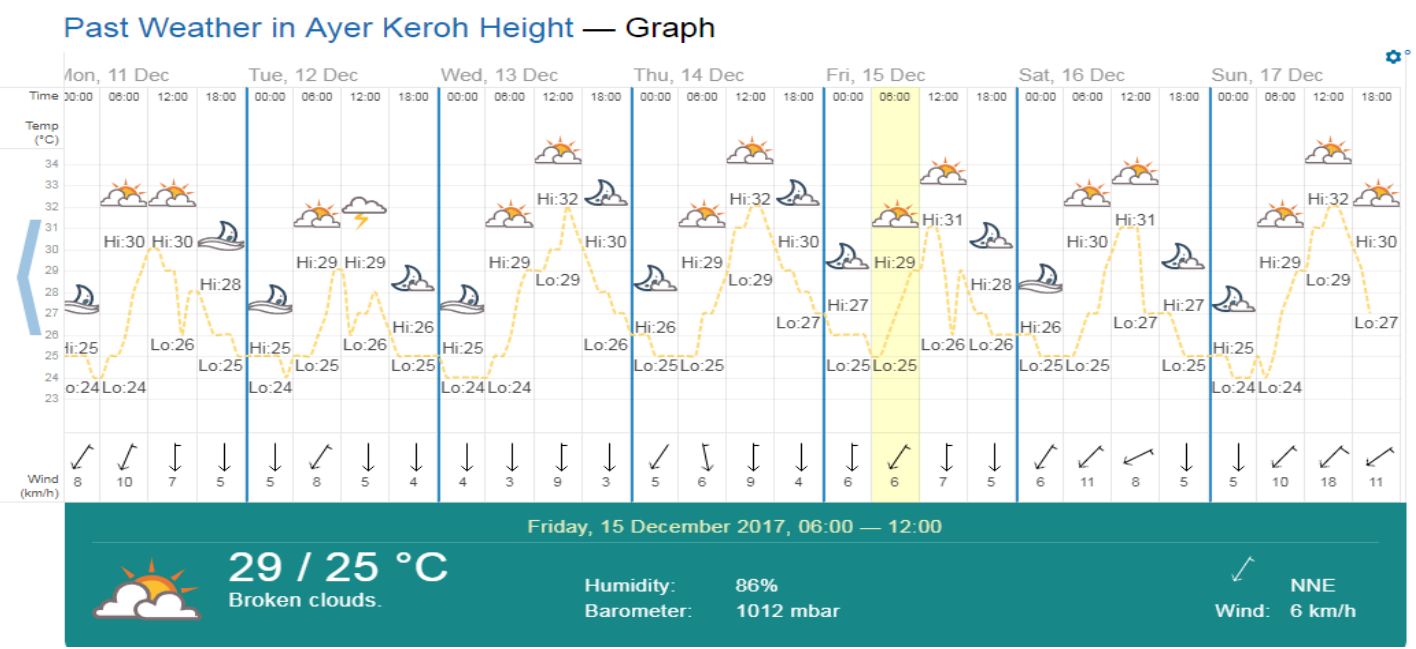

Figure 3. A weather condition at Ayer Keroh between 11th to 15th December 2017

\section{RESULTS AND ANALYSIS}

Figure 4 shows the energy produced by solar cells from 8:00 am to 5:00 pm with one-hour interval period. It reveals that the average power converted by the cell from solar radiation is approximately 562 milliwatts. As depicted, the highest conversion rate happened between 12:00 noon and 2:00 pm. The depletion of power in the morning and late evening is expected due to the shading on the solar cell.

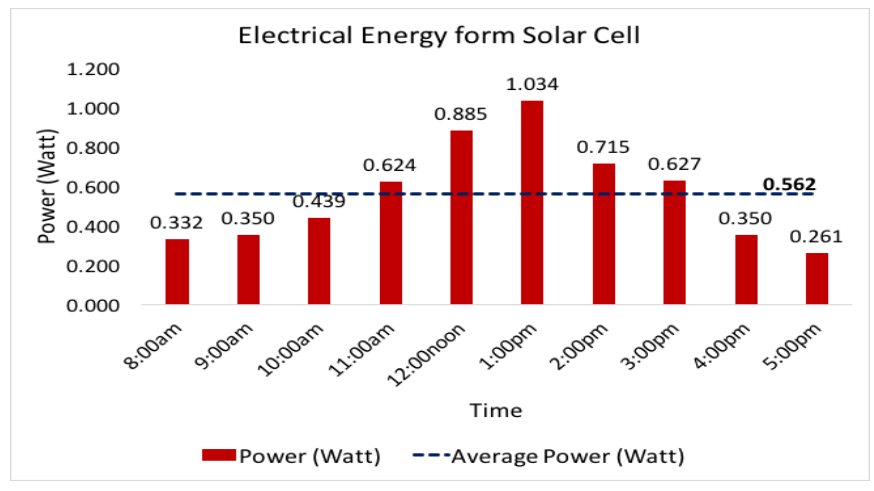

Figure 4. An electrical energy generated from solar cell module

On the other hand, Figure 5 shows energy generated by the pico-hydro module with different head levels. The plot disclosed that the power increased proportionally with the head level. This experiment has generated 110 milliwatts of average power over 10 different head levels. This finding is coherent with the finding of [7] as well as estimated power by (1). The Pico-hydro module is obviously generating less power compared to its solar counterpart as it required more efficient generator as well as higher head value.

The experiment with combined system has managed to generate an average energy reaching 921 milliwatts with peak power exceeded one thousand milliwatts threshold. This yields more than $50 \%$ boost in term of energy production compared to the individual module. Graph in Figure 6 shows the electrical energy generated by the hybrid system for each day, from December 11th to December 15th 2017. 


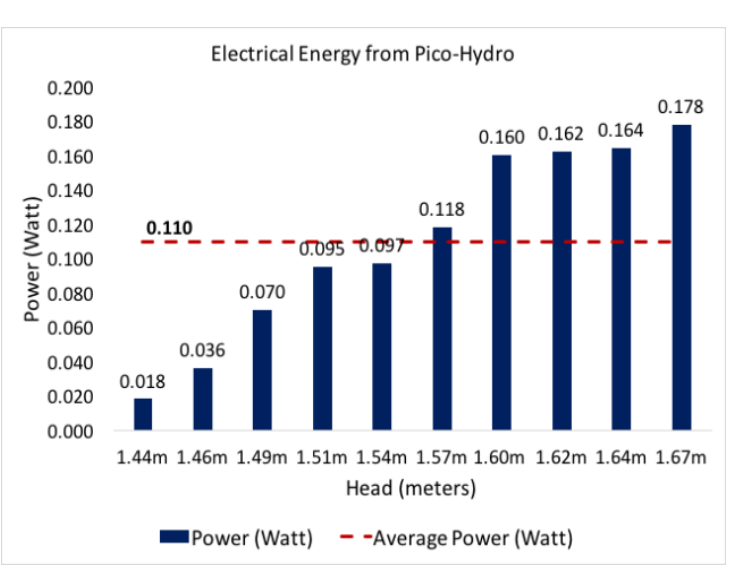

Figure 5. An electrical energy generated from pico-hydro module

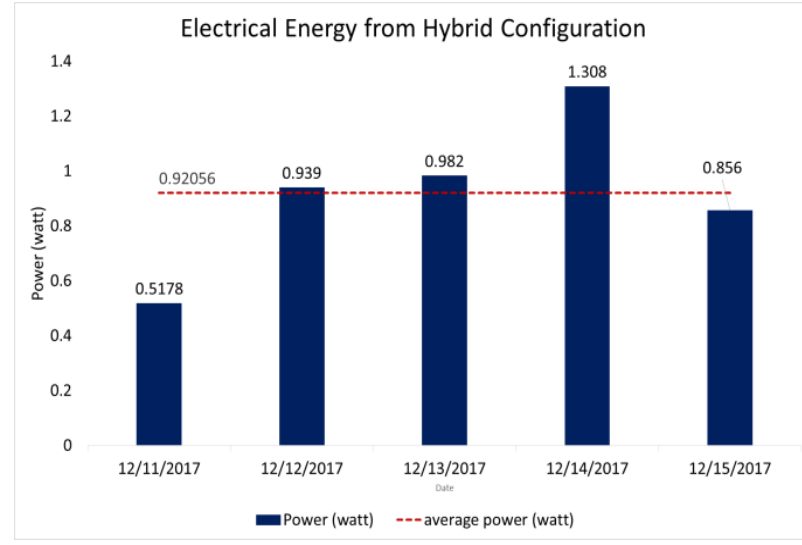

Figure 6. An electrical energy generated from hybrid configuration

\section{CONCLUSION}

In conclusion, a combination of two modules as a hybrid system for generating energy has produced consistent output at different weather conditions especially for remote areas in the equatorial region. Taken together, these results suggest there is a great opportunity to breed an electricity from both resources. Therefore, the project would encourage further studies on hybrid power generation from the natural resources especially for those in tropical and equatorial area.

\section{ACKNOWLEDGEMENTS}

This project is supported by Universiti Teknikal Malaysia Melaka (grant number: PJP/2017/FTKHI14/S01546).

\section{REFERENCES}

[1] A. M. Mahmud, R. E. Blanchard, "Assessing a rural electrification program in Malaysia: System performance analysis on 11 solar PV-diesel hybrid systems," in International Conference on the Development in the Renewable Energy Technology (ICDRET), Dhaka, 2016, pp. 1-5

[2] A. Al-Mamun et al., "Design and development of a low cost solar energy system for the rural area," in IEEE Conference on Systems, Process \& Control (ICSPC), Kuala Lumpur, 2013, pp. 31-35.

[3] A. Thalamttathu Thankappan, S. P. Simon, P. S. R. Nayak, K. Sundareswaran and N. P. Padhy, "Pico-hydel hybrid power generation system with an open well energy storage," IET Generation, Transmission \& Distribution, vol. 11, no. 3, pp. 740-749, 2017.

[4] P. Chrin, M. Pietrzak-David and P. Maussion, "Renewable electricity production with some wasted second-life components," in 25th International Symposium on Industrial Electronics (ISIE), 2016, pp. 574-579.

[5] K. C. Anup, G. Poudel, S. Poudel and M. Khadka, "Hydro Home System - an inventory on rural electrification," in International Conference on Computer and Automation Engineering (ICCAE), Singapore, 2010, pp. 338-341.

[6] M.F.Yaakub, M.F.Basar, M.S. Yahaya, F.H.M.Noh. H.Z.Kamarudin, “A Micro-Power Generation From Rain Shower Utilizing PZT and PVDT Piezoelectric Transducer", ARPN Journal of Engineering and Applied Sciences, vol.12, no.22, pp. 6285-6290, 2017

[7] M Faizal Yaakub, M Farriz Basar, F Hanim Mohd Noh, Hambali Boejang, "Pico-hydro Electrification from Rainwater's Gravitational Force for Urban Area”, TELKOMNIKA, vol.16, no.3, pp. 997-1003, 2018.

[8] H. Zainuddin , A. Khamis , M. S. Yahaya , M. F. M. Basar , J. M. Lazi and Z. Ibrahim, "Investigation on the Performance of Pico-hydro Generation System Using Consuming Water Distributed to Houses", International Journal of Electrical, Computer, Energetic, Electronic and Communication Engineering,vol3.iss.11, pp1-4, 2009.

[9] M.F. Basar, A. Ahmad, N. Hasim, K. Sopian, "Introduction to the Pico Hydro Power and the Status of Implementation in Malaysia", Proceedings - 2011 IEEE Student Conference on Research and Development, SCOReD 2011, pp.283-288

[10] Shaleen Martin, K. K. Shrivastava, "Feasibility of Rainwater Harvesting in High rise Building for Power Generation", International Journal of Engineering Trends and Technology, vol, iss.4, pp.522-527,2013.

[11] G. Subhashini, Devindran Munandy, Raed Abdulla, "Generating a Lighting System by Using Pico Hydro System", TELKOMNIKA, vol.15.iss.4, pp.1585-1573, 2017

[12] Ciro Spataro, Fabio Viola, Pietro Romano, Rosario Micel, "Performances of rainfall energy harvester", 18th International Workshop on ADC Modelling and Testing Research on Electric and Electronic Measurement for the Economic Upturn, pp. 467-472, 2014 
[13] O Yaakob, YM Ahmed, A Elbatran, H Shabara. A Review on Micro Hydro Gravitational Vortex Power and Turbine Systems. Jurnal Teknologi. 2014; 69(7).

[14] BAH Elbatrana, WA Mohamed, COB Yaakobb, MD Yasser, AI Arif. Hydro Power and Turbine Systems Reviews. Jurnal Teknologi. 2015; 74(5).

[15] P Komgrich, W Kanit. Innovation of Hydro Power Generator from Waste Energy to Green Marketing. International Journal of Business and Social Science. 2012; 3(12): 37-44.

[16] R Gopal, P Saajan. Pico Hydro System. International Journal of Innovations in Engineering Research and Technology [IJIERT]. 2015; 2(4): 1-8,

[17] V Seema, VA Vijay, J Akshay, R Sujata. Modification and Performance Evaluation of Pico-Hydro Power Generation Unit. International Journal of Agricultural Sciences. 2016; 12(1): 85-89.

[18] Y Gunjian, AK Chauhan. Design and Development of Pico Micro Hydro System by Using House Hold Water Supply. International Journal of Research in Engineering and Technology. 2014; 03(22): 114- 119.

[19] N.Sivaramakhrisna, Ch.Kasi Ramakrishna Reddy, "Hybrid Power Generation through combined solar -wind power and modified solar panel", International Journal of Engineering Trends and Technology (IJETT), vol.4, iss.5, pp.1414-1417, 2011.

[20] Anilkumar, Sishaj, Panugothu, Kinattingal, Narayana, “ Pico-hydel hybrid power generation system with an open well energy storage”, IET Generation, transmission \& Generation, vol.11, iss.3, pp.740-749, 2017.

[21] V. Thiruchelvam and G. T. J. Ao, "Design and implementation of a hybrid solar wind energy tower, " in Conference on Control Applications (CCA), Sydney, NSW, 2015, pp. 371-375.

[22] M.F. Yaakub, S. Abdullah, M.F. Basar, F.H. Mohd Noh , M.H.Harun, M.F.M.A Halim, "Energy conversion: A study on rainfall's gravitational force for urban area power generation", Proceedings of Mechanical Engineering Research Day 2017, pp. 166-167, May 2017

[23] A. Syafrina, M. Zalina, L. Juneng, "Historical trend of hourly extreme rainfall in Peninsular Malaysia", Journal of Theoretical and Applied Climatology, vol.120, iss.1, pp.259-285, 2015.

[24] C. L. Wong, R. Venneker, S. Uhlenbrook, A. B. M. Jamil, and Y. Zhou, "Variability of rainfall in Peninsular Malaysia", Hydrology and Earth System Sciences Discussions, vol.6, iss.4, pp.5471-5503, 2009

[25] S. Mekhilef, A.Safari, W.E.S. Mustaffa, R.Saidur, R.Omar, M.A.A. Younis, "Solar energy in Malaysia: Current state and prospects”, Journal of Renewable and Sustainable Energy Review, vol.16, iss.1, pp.386-396, 2012.

\section{BIOGRAPHIES OF AUTHORS}

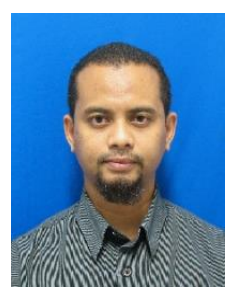

Muhamad Faizal Yaakub received his BEng in Electronics Engineering (2004) and MEng in Electrical Power Engineering (2013) form Universiti Teknologi Malaysia and Universiti Tun Hussein Onn Malaysia respectively. He is registered with Engineering Council UK as a Chartered Engineer (CEng) and with Malaysian Board of Technology as a Professional Technologist (Ts). Currently, he is a lecturer and researcher at Universiti Teknikal Malaysia Melaka. His primary interests related to power electronics, inverters and renewable energy.

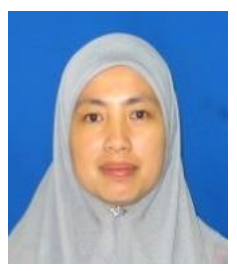

Faridah Hanim Mohd Noh has received her Doctor of Philosophy (Electrical) from Kumamoto University, Japan in 2016. She is currently a Senior Lecturer in Universiti Tun Hussein Onn Malaysia. She received her MEng. (Electrical) from University Tun Hussein Onn Malaysia in 2008 and BEng. (Hons.) Electrical Power from Universiti Malaya, Malaysia in 2004. Her research interest is in power quality, advanced signal processing and renewable energy.

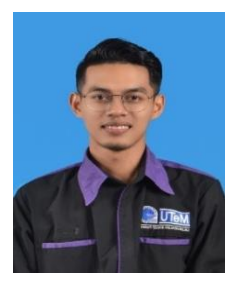

Muhammad Fahmie Izzudin bin Mohd Zali received his BEng Tech in Industrial Power from Universiti Teknikal Malaysia in 2018. He currently works as Project Engineer in Rankon Power Engineering \& Services Sdn Bhd.

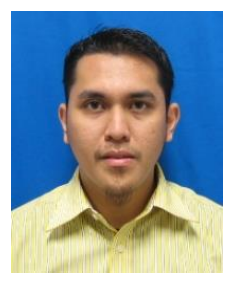

Mohamad Haniff Harun is a Senior Lecturer at Faculty of Electrical \& Electronic Engineering Technology, Universiti Teknikal Malaysia Melaka (UTeM). His primary interests related to vision system 